\title{
Effect of biomaterials and working pressure of a briquetting machine on physical characteristics and energy consumption of briquette production
}

\author{
Ignacy Niedziółka ${ }^{1, *}$, Maciej Sprawka ${ }^{1}$, Beata Zaklika ${ }^{1}$, Artur Kraszkiewicz², and Artur Przywara ${ }^{2}$ \\ ${ }^{1}$ Univeristy of Life Sciences, Department of Agricultural Machines, Głęboka 28, 20-612 Lublin, Poland \\ ${ }^{2}$ Univeristy of Life Sciences, Department of Machine Operation and Production Process Management, Głęboka 28, 20-612 Lublin, \\ Poland
}

\begin{abstract}
The paper presents an analysis of the influence of biomaterials and working pressure of a briquetting machine on physical characteristics and energy consumption of briquette production. The following types of biomaterials were used in the study: rape, oat and maize straw. Hydraulic piston briquetting machine JUNIOR manufactured by Deta Polska was used for briquetting. During the briquetting process, the working pressures of briquetting machine were 20, 26 and $32 \mathrm{MPa}$. Depending on the type of biomaterial used and the assumed working pressure of briquetting machine, produced briquettes differed in terms of both their physical characteristics and energy consumption. Based on the analysis of the obtained results, it was found that physical characteristics and energy consumption during briquette production were influenced by such factors as the type of compacted material, its fragmentation as well as granulometric composition and working pressure of the briquetting machine used.
\end{abstract}

\section{Introduction}

Biomass is the world's third largest Renewable Energy Source (RES). It is worth using for energy purposes, because biofuels are not harmful to the environment. The amount of carbon dioxide emitted into the atmosphere during its combustion, is balanced by the amount of $\mathrm{CO}_{2}$ absorbed by plants that reproduce the biomass by means of photosynthesis [1]. In addition, attention should be paid to the declining resources of fossil fuels as well as to the environmental pollution caused by conventional energy using these sources. This contributes to the increased interest in RES. The current trends in the development of power industry are aimed at increasing the use of RES, including biomass [2].

Biomaterials from agricultural and forestry production are the main source of renewable energy in Poland and represent a significant energy potential. These include by-products and waste from agriculture, forestry and agri-food industry [3]. The plant biomass in its unprocessed state, is characterized by low bulk density, making its transport, storage and practical use difficult. For these reasons, there is a need for its agglomeration in the form of pellets or briquettes [4-7]. These biofuels are made of finely fragmented biomass under the influence of suitable pressure and temperature, most often without the addition of any binder. The pressure and temperature occurring during the agglomeration process result in a significant reduction in the volume of compacted biomaterials [8-
10]. This also results in a decrease in water content, increased concentration of mass and energy, as well as distribution and use of biofuels produced. Furthermore, the use of biomass in a compact form allows the parametric unification of the fuel, automation of its dosage in the combustion process and obtaining a competitive energy source $[11,12]$.

Solid biofuels produced from plant biomass arouse interest mainly among distributed energy producers as well as individual consumers. At present, professional energy production is reluctant to use biomass as a fuel in power systems. This is due, among others, lower quality of this kind of fuel and also the instability of its supply. However, it is necessary to look for alternative fuels for the energy sector, hence the aim is to use different types of plant biomass for these purposes [1315]. New technological solutions using plant fuels to produce electricity and heat, are also sought. The existing technologies for the management of biomass surpluses from agricultural, forestry and orchard production, are also being improved. Growing demand for electricity, as well as a trend towards environmental protection, is driving the search for alternative energy sources [16].

\section{Material and methods}

Moisture content of biomaterials was determined using the RADWAG MAX 50/1/WH laboratory drier.

\section{*Corresponding author: ignacy.niedziolka@up.lublin.pl}


Samples of wet materials were placed in a drying chamber of the weighing-drying device and then dried at $120^{\circ} \mathrm{C}$ to a constant weight according to the standard PN-EN 15414-3:2011. The calorific value of biomaterials was determined on the basis of the combustion heat determined by means of calorimetric method using an isoperybolic calorimeter of Parr 6400 type. Samples weighing $100 \mathrm{~g}( \pm 1 \mathrm{~g})$ were taken for the sieve analysis and a laboratory shaker with a set of sieves was applied: $3.15,2.8,2.0,1.4,1.0,0.5,0.25$ $\mathrm{mm}$, according to the standard PN-EN 15149-2:2011.

Following biomaterials were used for the production of briquettes: rape, oat and maize straw. These materials were crushed using a $\mathrm{H}$ 111/1 type rotary shredder driven by an electric motor of $7.5 \mathrm{~kW}$ and equipped with a screen with a diameter of $20 \mathrm{~mm}$. For briquetting of the crushed materials, a hydraulic piston briquetting machine of JUNIOR type manufactured by Deta Polska, was used. During this process, a double feed hopper was applied to the briquetting compaction chamber and three working pressures were applied: 20, 26 and $32 \mathrm{MPa}$.

Measurements of the physical characteristics of produced briquettes included: length, diameter and weight. Samples of briquettes weighing $1000 \mathrm{~g}( \pm 10 \mathrm{~g})$ were taken for measurements performed in 5 replicates. Geometric dimensions of briquettes were determined by means of a caliper with a measurement accuracy of \pm 1 $\mathrm{mm}$ while their mass using a laboratory scale with an accuracy of $\pm 0.1 \mathrm{~g}$.

Briquette bulk density was determined on the basis of measurements of their physical characteristics and calculated according to the formula (1):

$$
\rho_{w}=\frac{4 \cdot 10^{6} \cdot m}{\pi \cdot d^{2} \cdot l}\left(\mathrm{~kg} \cdot \mathrm{m}^{-3}\right)
$$

where: $\rho_{\mathrm{w}}$ - briquette bulk density $\left(\mathrm{kg} \cdot \mathrm{m}^{-3}\right)$, $\mathrm{m}$ - mass of briquette $(\mathrm{g})$,

$\mathrm{d}$ - outer diameter of briquette $(\mathrm{mm})$,

1 - length of briquette $(\mathrm{mm})$.

Measurements of mechanical durability of briquettes were carried out on a test bench in accordance with standard PN-EN 15210-2:2011. The rotational speed of the cylinder was $21 \mathrm{rpm}( \pm 0.1 \mathrm{rpm})$, a test time of 5 min, and a sample weight of $2000 \mathrm{~g}( \pm 100 \mathrm{~g})$. After the durability test, the briquettes were screened on a 31.5 $\mathrm{mm}$ diameter screen. The mechanical durability of briquettes was calculated according to the formula (2):

$$
\mathrm{D}_{\mathrm{U}}=\frac{\mathrm{m}_{\mathrm{A}}}{\mathrm{m}_{\mathrm{E}}} \cdot 100(\%)
$$

where: $\mathrm{D}_{\mathrm{U}}-$ mechanical durability of briquettes (\%), $\mathrm{m}_{\mathrm{A}}-$ mass of briquettes after durability test $(\mathrm{g})$, $\mathrm{m}_{\mathrm{E}}-$ mass of briquettes before durability test $(\mathrm{g})$.

A specialized registration system was used to measure the energy consumption of the briquetting process of the biomaterials tested. This system uses Lumel N14 electrical network parameters meter, developed with current transformers. With its use, energy consumption was recorded and referred to the resulting briquette mass.

Achieved results of briquettes testing were subjected to statistical analysis using a two-factor analysis of variance and Tukey's test. For this purpose, the SAS Enterprise Guide 5.1 software was used. For statistical analysis, the level of significance $\alpha=0.05$ was assumed. The obtained analysis results will allow to evaluate the influence of the adopted factors on tested briquette characteristics.

\section{Results and discussion}

Prior to the briquetting process of biomaterials, their moisture content and calorific value were determined. Based on the achieved results, it was found that the moisture content of materials used for the production of briquettes ranged from 12.8 to $13.5 \%$, while their calorific value was within the range of $16.5-17.3 \mathrm{MJ} \cdot \mathrm{kg}^{-}$ ${ }^{1}$ (Table 1).

Table 1. Moisture content and calorific value of biomaterials used for briquetting.

\begin{tabular}{|c|l|c|c|}
\hline No. & $\begin{array}{l}\text { Kind of } \\
\text { biomaterial }\end{array}$ & $\begin{array}{c}\text { Moisture } \\
(\mathbf{\%})\end{array}$ & $\begin{array}{c}\text { Calorific value } \\
\left(\mathbf{M J} \cdot \mathbf{k g}^{-\mathbf{1}} \mathbf{)}\right.\end{array}$ \\
\hline 1. & Rape straw & 12.8 & 16.5 \\
\hline 2. & Oat straw & 13.1 & 16.8 \\
\hline 3. & Maize straw & 13.5 & 17.3 \\
\hline
\end{tabular}

Table 2 presents results of granulometric analysis of raw materials used in the production of briquettes. The particle size depended on the nature of raw material and its susceptibility for grinding. The highest particle mass of $3.15 \mathrm{~mm}$ was found for maize straw (85.2\%), significantly lower for oat straw (46.3\%), and lowest for rape straw $(31.6 \%)$. The smallest mass share of the dusty fraction $(<0.5 \mathrm{~mm})$ was recorded for maize straw $(2.3 \%)$, higher for oat straw $(5.1 \%)$, while largest for rape straw $(9.1 \%)$.

Table 2. Granulometric composition of materials used in the production of briquettes (\%).

\begin{tabular}{|l|c|c|c|c|c|c|c|c|}
\hline \multicolumn{1}{r}{ Meshes of sieve (mm) } & $\mathbf{3 . 1 5}$ & $\mathbf{2 . 8}$ & $\mathbf{2 . 0}$ & $\mathbf{1 . 4}$ & $\mathbf{1 . 0}$ & $\mathbf{0 . 5}$ & $\mathbf{0 . 2 5}$ & $\mathbf{0 . 0}$ \\
Kind of biomaterial & & & & & & & & \\
\hline Rape straw & 31.6 & 1.9 & 5.7 & 16.1 & 21.2 & 14.4 & 5.2 & 3.9 \\
\hline Oat straw & 46.3 & 2.2 & 6.3 & 12.5 & 15.4 & 12.2 & 3.2 & 1.9 \\
\hline Maize straw & 85.2 & 0.8 & 0.5 & 1.9 & 3.6 & 5.7 & 1.6 & 0.7 \\
\hline
\end{tabular}


Figure 1 shows the results of briquette length measurements for the materials tested and the assumed pressure values.

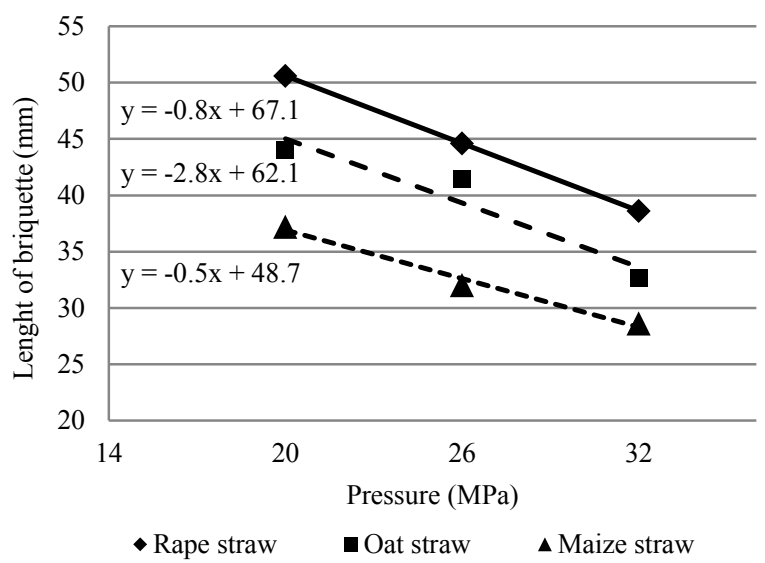

Fig. 1. Average length of briquettes depending on the type of raw material and working pressure of briquetting machine.

For rapeseed straw briquettes, the average length decreased from 50.6 to $38.6 \mathrm{~mm}$, for oat straw from 44.0 to $32.6 \mathrm{~mm}$ and for maize straw from 37.2 to 28.6 $\mathrm{mm}$. Analysis of the data revealed that with an increase in working pressure from 20 to $32 \mathrm{MPa}$, the briquette length decreased by $31 \%$ for rape straw, by $35 \%$ for oat straw, and by $30 \%$ for maize straw. There were statistically significant differences between the briquette length produced from studied raw materials and the working pressure of briquetting machine.

Figure 2 shows the results of mass measurements of briquettes produced from compacted raw materials and assumed pressure values. The lowest mass was obtained for maize straw briquettes (38.6-43.1 g), higher for oat straw (50.4-61.4 g) and highest for rape straw (74.7$81.3 \mathrm{~g})$. The analysis of achieved data suggests that, with increasing working pressure, the weight of briquettes increased by approximately 12, 22 and $9 \%$. There were statistically significant differences between the mass of briquette produced from tested raw materials and the assumed working pressure of the briquetting machine.

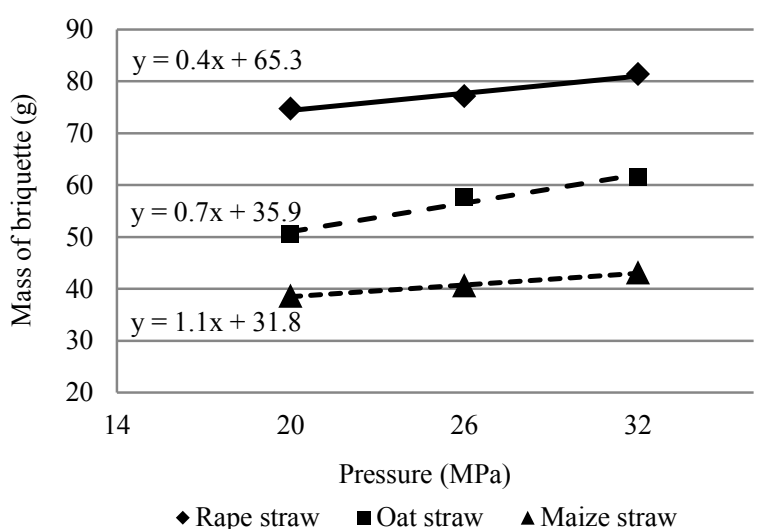

Fig. 2. Average mass of briquettes depending on the type of raw material and working pressure of briquetting machine.
Figure 3 illustrates results of briquette bulk density studies for compacted raw materials and assumed pressure values. The lowest density was recorded for briquettes made of maize straw (530-766 kg m$\left.{ }^{-3}\right)$, higher for oat straw $\left(589-964 \mathrm{kgm}^{-3}\right)$, whereas highest for rape straw (753-1075 $\left.\mathrm{kgm}^{-3}\right)$. Analysis of the obtained data shows that, with increasing working pressure, the briquette bulk density increased by approximately 45,64 and $43 \%$. There were statistically significant differences between the bulk density of briquettes produced from tested raw materials and the assumed working pressure of the briquetting machine.

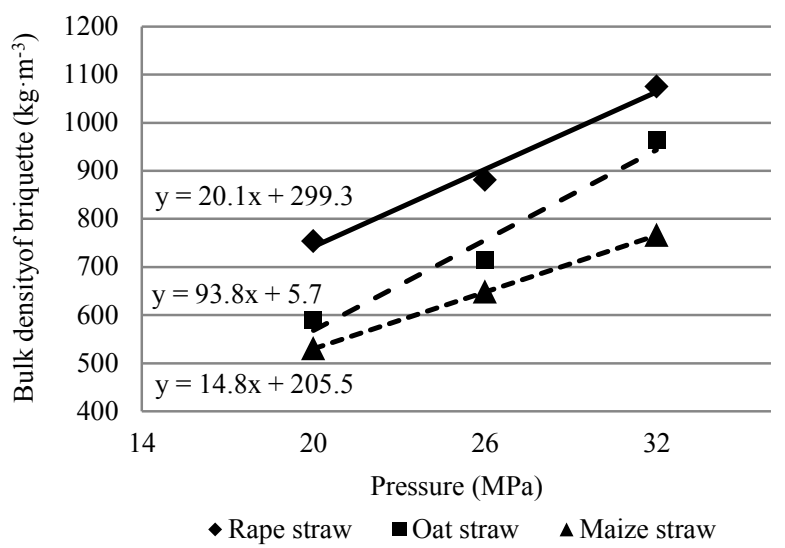

Fig. 3. Average bulk density of briquettes depending on the type of raw material and working pressure of briquetting machine.

Figure 4 shows results of mechanical durability tests of briquettes depending on the type of raw material and working pressure of the briquetting machine. For the assumed working pressure, the lowest mechanical durability was recorded for maize straw briquettes, significantly higher for rape straw, and the highest for briquettes made of oat straw. The analysis of achieved obtained data revealed that the increase in working pressure from 20 to $32 \mathrm{MPa}$ increased the mechanical durability of briquettes from 13 to 16 percentage points.

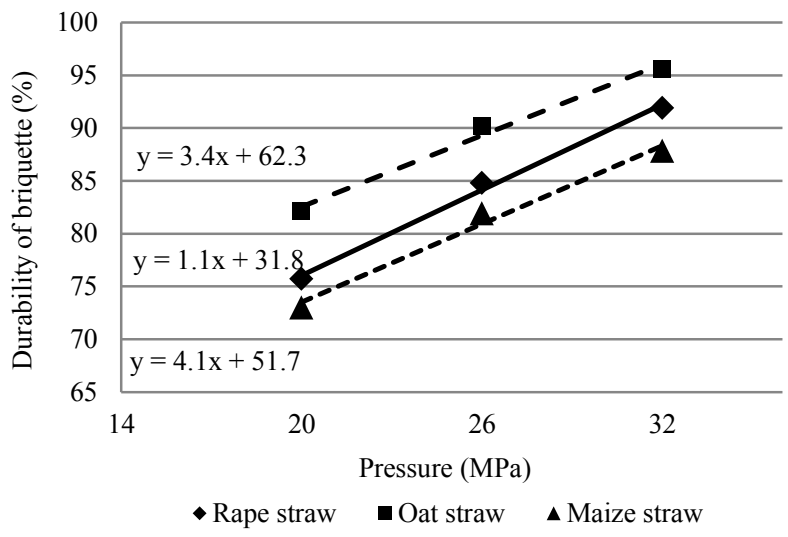

Fig. 4. Average mechanical durability of briquettes depending on the type of raw material and working pressure of briquetting machine.

Figure 5 shows results of the energy consumption tests for briquette production depending on the type of raw material and working pressure of the briquetting machine. 
For rape straw briquettes, the average energy consumption of the production was within the range of 109-137 Wh $\mathrm{kg}^{-1}$, for oat straw 114-129 Wh $\mathrm{kg}^{-1}$ and for maize straw $122-145 \mathrm{Wh} \cdot \mathrm{kg}^{-1}$. Analysis of the data showed that with an increase in working pressure from 20 to $32 \mathrm{MPa}$, the energy consumption of rape straw briquette production increased by about $26 \%$, for oat straw by $13 \%$, and for maize straw by $19 \%$.

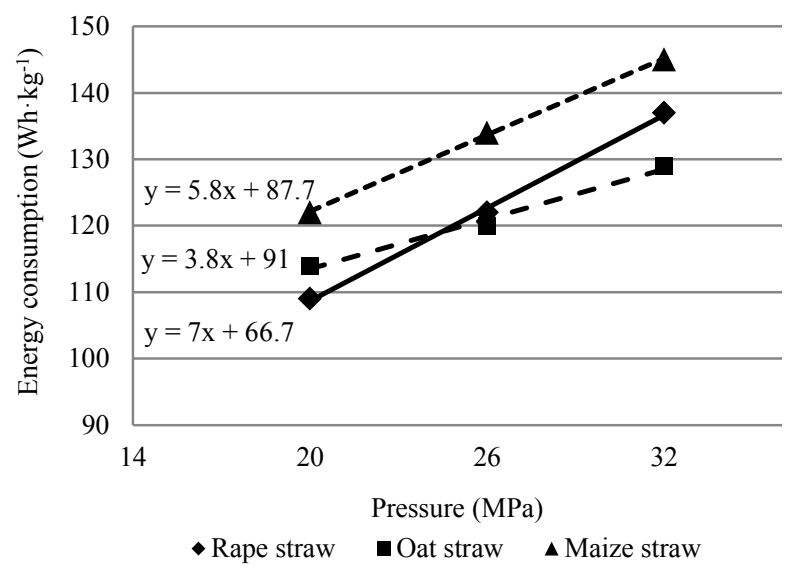

Fig. 5. Average energy consumption of briquettes production depending on the type of raw material and working pressure of briquetting machine.

\section{Conclusions}

1. Depending on the type of biomaterial used and the assumed working pressure of briquetting presses, resulting briquettes differed significantly both in terms of their physical characteristics and their production energy consumption.

2. It was found that with the increase in the pressure of briquetting machine, the briquette length decreased by $30-35 \%$, while their weight increased by $9 \%$ for rape straw, $12 \%$ for maize straw, and $22 \%$ for oat straw.

3. Increasing the working pressure of briquetting machine from 20 to $32 \mathrm{MPa}$ resulted in an average of 1.5 times the bulk density of produced briquettes. The lowest bulk density was recorded for maize straw compacted at $20 \mathrm{MPa}\left(530 \mathrm{~kg} \cdot \mathrm{m}^{-3}\right)$, whereas the highest for rape straw at $32 \mathrm{MPa}\left(1075 \mathrm{~kg} \cdot \mathrm{m}^{-3}\right)$.

4. Mechanical durability of briquettes depended both on the type of material to be compacted and working pressure of the briquetting machine. The lowest durability of briquettes was recorded when compacting maize straw (73-88\%), while highest for oat straw (82-96\%).

5. Analysis of achieved results showed that the physical characteristics and energy consumption of briquette production were influenced by such factors as: type of compacted material, fineness and granulometric composition, as well as working pressure of briquetting machine.
1. B.M. Jenkins, L.L. Baxter, T.R. Miles jr., T.R. Miles, Fuel Process. Tech., 54, 17 (1998)

2. I. Niedziółka (red.), Technika produkcji brykietów $z$ biomasy roślinnej (Libropolis Lublin, 2014)

3. A. Grzybek, P. Gradziuk, K. Kowalczyk, Stoma energetyczne paliwo (Wieś Jutra Sp. z o.o., Warszawa, 2001)

4. V. Panwar, B. Prasad, K. Wasewar, J. Energy Eng., 137/2, 108 (2011)

5. M.K. Sharma, P. Gohil, N. Sharma, Am. J. Eng. Res. (AJER), 04/02, 44 (2015)

6. S. Mani, L.G. Tabil, S. Sokhansanj, Powder Handl. Process., 15, 160 (2003)

7. I. Niedziółka, M. Szpryngiel, M. KachelJakubowska, A. Kraszkiewicz, K. Zawiślak, P. Sobczak, R. Nadulski, Renew. Energy, 76, 312 (2015)

8. R. Hejft, S. Obidziński, J. Res. Appl. Agric. Eng. 60(1), 19 (2015)

9. I. Niedziółka, B. Zaklika, M. Kachel-Jakubowska, A. Kraszkiewicz, Ann. Wars. Univ. Life Sci.SGGW, Agric., (Agric. For. Eng.), 68, 51 (2016)

10. N. Kaliyan, R.V. Morey, Biomass Bioenerg., 33, 337 (2009)

11. S. Bielski, B. Dubis, K. Jankowski, Przem. Chem. 94/10, 1798 (2015)

12. J. Carroll, J. Finnan, Biosys. Eng.,112, 151 (2012)

13. P. Mc Kendry, Bioresource Technol., 83, 37 (2002)

14. I. Niedziółka, M. Szymanek, Teka Komis. Mot. Energ. Rol., X, 301 (2010)

15. S. Vassilev, D. Baxter, L. Andersen, C. Vassileva, Fuel, 89, 913 (2010)

16. P. Gradziuk, Biopaliwa (Wieś Jutra Sp. z o.o., Warszawa, 2003)

\section{References}

